\title{
Six Ways to Improve the Profitability of Lychee in South Florida ${ }^{1}$
}

Edward Evans, Robert Degner, and Kimberly Morgan²

\section{Introduction}

Lychee (Litchi chinensis Sonn.) is a difficult crop for farmers in south Florida to grow and market for the following reasons:

- Yields can vary widely due to irregular flowering and poor fruit retention.

- Fruit is susceptible to a broad range of pests and diseases and can suffer heavy losses to birds and fruit bats in some areas if not netted.

- The production season is short.

- Fruit is highly perishable, susceptible to browning and rotting and requires special treatment at harvesting.

- Harvesting can be very labor intensive and costly.

Yet, despite these many production and marketing problems, producing the fruit can be quite rewarding, with average returns for lychee easily matching or surpassing those from other produce grown in the area. In addition, there is a growing demand in the United States for lychees, fueled mainly by increasing Asian ethnic populations in the United States and curious or health-conscious consumers who purchase fruit in specialty stores.

Recently there have been concerns as Florida growers' profits from lychee have steadily declined. For example, in the 1990s, average returns for lychee were about $\$ 8,000$ per acre. Today, average returns have dropped to about $\$ 2,500$ per acre, assuming modest to high yields. The main reason for the sharp decline in prices is market competition from imports coming from Taiwan, China, and Mexico. From 2000 to 2003 , U.S. imports of lychee grew from 536 tons to 3,346 tons (about 524 percent). The bulk of the increase was due to imports from Taiwan. In 2002, Taiwan doubled its lychee exports to the United States, overtaking Mexico as the main supplier to the U.S. market. Then in 2003, Taiwan increased its lychee exports to an all time high of 2,373 tons, or 70 percent of U.S. total imports. China is expected to surpass Taiwan with its test shipments of lychee to the United States in 2004. Increases in the U.S. import market have caused the U.S. domestic price for lychee to plunge dramatically, leaving many

1. This is EDIS document FE497, a publication of the Department of Food and Resource Economics, Florida Cooperative Extension Service, Institute of Food and Agricultural Sciences, University of Florida, Gainesville, FL. Published November 2004. Please visit the EDIS website at http://edis.ifas.ufl.edu.

2. Edward Evans, Assistant Professor, Department of Food and Resource Economics, Tropical Research and Education Center, Homestead, FL; Robert Degner, Professor and Director of Florida Agricultural Market Research Center, and Kimberly Morgan, Coordinator of Economic Analysis, Department of Food and Resource Economics, Florida Cooperative Extension Service, Institute of Food and Agricultural Sciences, University of Florida, Gainesville, FL.

The Institute of Food and Agricultural Sciences is an equal opportunity/affirmative action employer authorized to provide research, educational information and other services only to individuals and institutions that function without regard to race, color, sex, age, handicap, or national origin. For information on obtaining other extension publications, contact your county Cooperative Extension Service office. Florida Cooperative Extension Service/Institute of Food and Agricultural Sciences/University of Florida/Christine Taylor Waddill, Dean. 
growers wondering whether the industry can remain profitable. Further aggravating the situation is the strong demand for land by real estate developers in the area, which has enticed some growers to exit the industry.

While the decision of whether to remain in the lychee business, shift to alternative enterprises, or sell the land to the real estate developers is a personal decision, we offer some suggestions to growers on how to increase their returns from lychee.

Specifically, we discuss six ways to improve the profitability of lychee enterprises, with an emphasis on marketing.

\section{Improving Marketing Opportunities}

Virtually all lychees produced in Florida are sold fresh because the volume of production is too small to justify large-scale commercial processing facilities. Because the lychee production season is very short (five to six weeks), it is costly and difficult to establish and sustain marketing programs for lychees with major food retailing chains. However, higher returns may be obtained in the following six ways:

1. Cooperatives.

2. Pick-Your-Own.

3. Direct Selling to Consumers (Farmers Markets and Roadside Markets).

4. Organic Production.

5. Value Added Products.

6. Other Marketing Alternatives.

\section{Cooperatives}

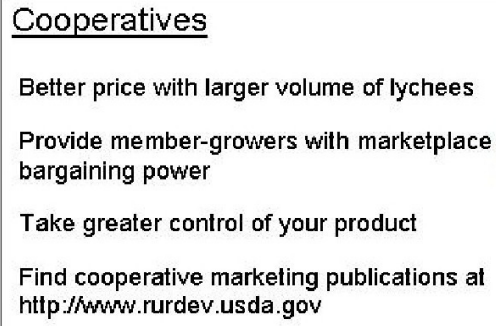

You can find information on farming cooperatives at "Florida Environments Online" (http://palmm.fcla.edu/feol). Use their website's pathfinder, "Florida Agriculture and Rural Life," to search for the publication by Doyle Edgar Timmons entitled "Co-operative agriculture in Florida: a survey of the development of the cooperative ventures in Florida and the United States." Although this publication is quite old, it remains an excellent source on cooperative farming information. The entire publication is available for download and printing purposes.

\section{Pick-Your-Own}

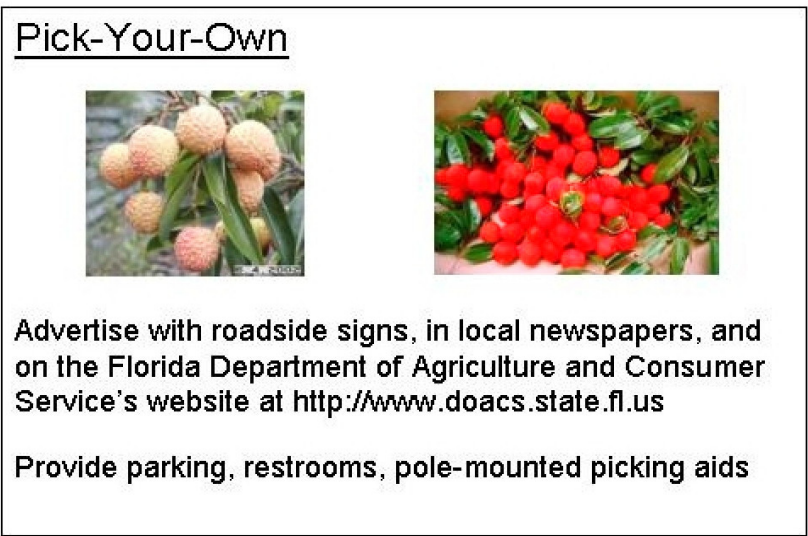

A pick-your-own operation will provide you with more profits, but will take considerably more time during the harvest season because you will need to:

- advertise with roadside signage, in local newspapers, and on the Department of Agriculture Web Site at http://www.doacs.state.fl.us.

- provide parking, pole-mounted picking aids and containers, restrooms, and drinking water.

- closely supervise customers to prevent damage to trees and to assure patrons' safety (particular attention should be paid to covering irrigation wells and to controlling insects such as fire ants and wasps.

- investigate to see if you need to carry extra liability insurance (pick-your-own operations are often outside the bounds of regular farm liability insurance). 
- give good service (it takes time to build up your business with repeat customers).

\section{Direct Selling to Consumers (Farmers' Markets and Roadside Markets)}

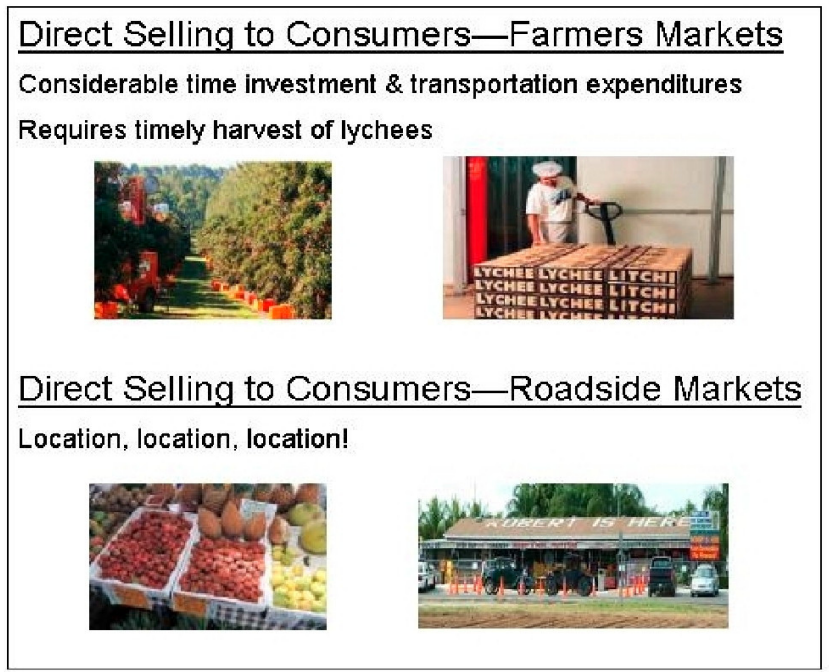

The United States Deparment of Agriculture's Agricultural Marketing Services has a website link for contact information (names, location, and hours of operation) for farmers' markets found throughout the state of Florida at http://www.ams.usda.gov/farmersmarkets/States/ Florida.htm. In addition, the Florida Department of Agriculture and the Consumer Services Bureau of State Farmers' Markets have website links to state farmers markets, fairs and expositions, and community farmers' markets as well as how-to publications and research articles at http://www.florida-agriculture.com/markets.htm.

Because many South Florida farmers markets have minimal produce available that coincides with the brief lychee season, there may be limited operational hours at nearby farmers market locations. It is important to contact managers at these locations early to arrange for space and to determine hours of operation.

Learn more about direct selling on Internet websites such as http://www.Redlandriot.com (click on "Burrs Berry Farm," "Knaus Berry Farm," and "Robert Is Here"). Location on well-travelled roads is essential and consideration must be made for safe access with adequate parking.

\section{Organic Production}

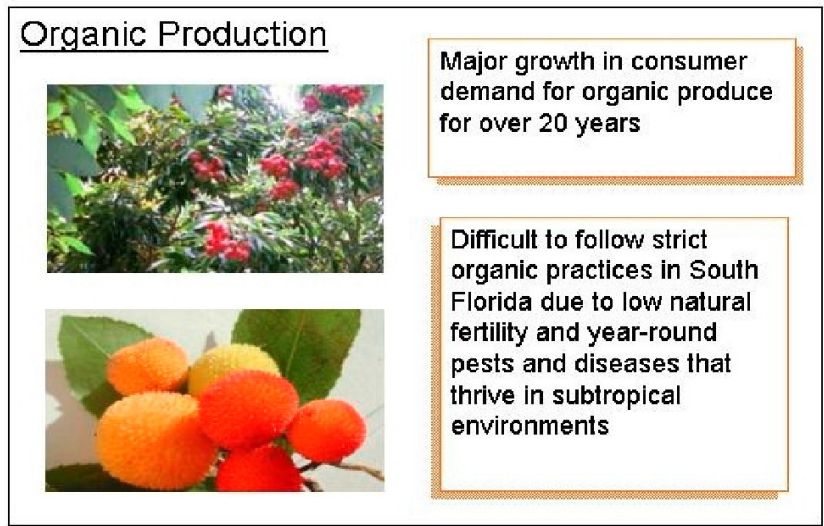

Given the ever-increasing market demand for organically grown or "green" produce, we recommend that lychee growers work with university and Extension specialists to experiment with ways to successfully develop, grow, and market viable organically-produced lychees. Currently, the cultural technology faces an array of problems, due in large part to the hot humid climate that characterizes South Florida, which fosters insect pests and diseases, making sustainable production of organic lychees difficult.

\section{Value Added Products}

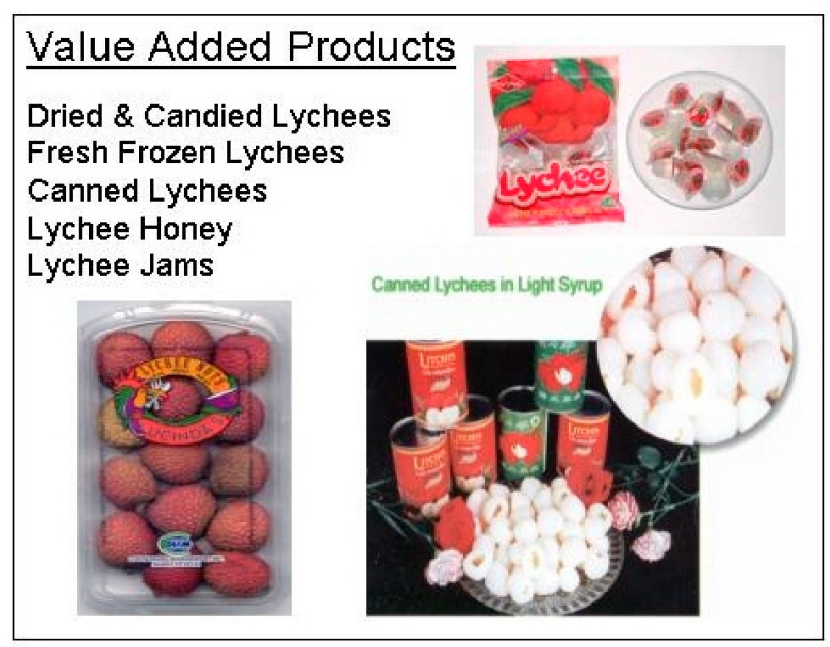

Adding value to lychees can be done by canning them whole or pitted, freezing, canning as preserves or jams, drying, or combining with other products like fruit cups or bakery goods. All of these processes serve to extend the shelf life of lychees and present a key marketing diversification approach, given the extremely limited supply window. In these product 
forms, lychees can be marketed year-round to supermarkets and food service outlets in Florida.

\section{Other Marketing Alternatives}

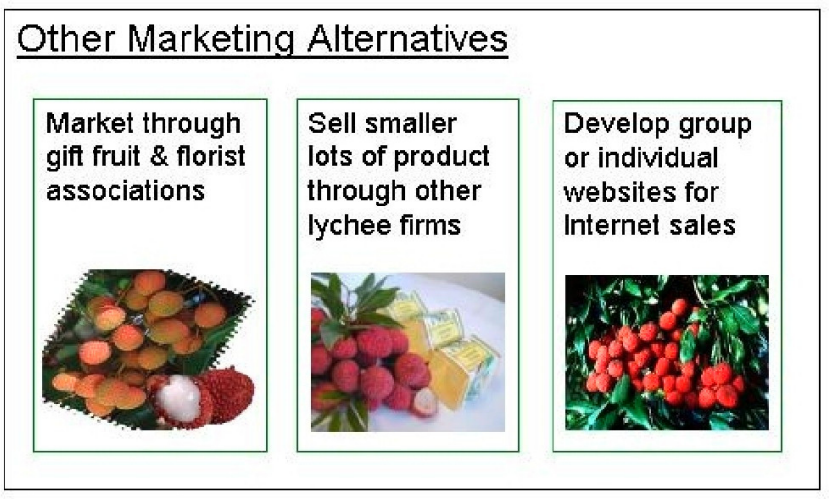

The Florida Gift Fruit Association (http://www.fgfsa.com) specializes in shipping Florida-grown citrus products nationally and internationally, and some of their member firms may add lychees or lychee products to their gift baskets. The Florida Department of Agriculture and Consumer Services offers promotional assistance, including website development and hosting, promotional materials, demographic consumer information, current research articles, etc. There is extensive online material concerning the "Fresh from Florida" Florida Agricultural Promotional Campaign at http://www.florida-agriculture.com/marketing/ index.htm. In addition, small lychee growers may be able to sell smaller lots of lychees via the Internet by developing their own websites or by selling through successful firms such as LycheesOnline.com.

\section{Final Remarks}

Although the golden days of very high returns from lychee are probably over, profitable lychee production is still possible. The success or failure of this enterprise, as far as profitability is concerned, will mainly be determined by the marketing decisions that are made. As with any other crop, profitable production starts with the identification of market opportunities.

\section{Contact Information}

Robert L. Degner

Professor \& Program Director

Food and Resource Economics Department

Post Office Box 110240

University of Florida

Gainesville, FL 32611

Phone: 352-392-1881 x 454

Email: RLDdegner@ifas.ufl.edu

Edward A. Evans

Assistant Professor

Tropical Research and Education Center

18905 SW 280th Street

Homestead, FL 33031

Phone: 305-246-7000 x 272

Email: EAEvans@ifas.ufl.edu 